\title{
UK universities urged to join forces to boost research
}

[LONDON] Closer collaboration between British universities, aimed at creating world-class research centres and widening access to the latest research equipment, has been suggested by the government in a paper from the Department for Education.

But government officials appear to be backing away from the idea, which some were actively promoting last summer, that leading research universities should be identified as belonging to a 'superleague', with privileged access to research funds.

The government's suggestions come in a paper submitted by the department to a national commission that is looking into the future size and structure of higher education. The review is being chaired by Sir Ron Dearing, a former civil servant.

Both the Conservative and the Labour parties have indicated that, whichever wins the general election due to be held within the next three months, the next government is likely to accept many of Dearing's proposals.

The main focus of the inquiry has been to review the financing of universities, and in particular how many students universities should accept, and how much students should pay towards their education. But its remit includes all aspects of the way that higher education institutions operate.

On the question of research, the department's main suggestion is that serious consideration should be given to increasing the concentration of research funds and to promoting stronger links between universities and local communities.

According to the department's paper: "Any method of allocating public funding for research should allow for fruitful collaboration and the emergence of new groupings of researchers. The rising cost of support infrastructure gives a further impetus to this development."

In parallel with this, the department points out that the mounting costs of investing in research infrastructure argue in favour of the concentration of resources and against "significant turnover in the departments receiving research funding".

Such a move would have widespread support among the research councils. John Krebs, for example, chief executive of the Natural Environment Research Council, writes in a foreword to his council's annual report, published last week, that there is a "common perception" that "the limited resources available for supporting research are spread too thinly and that greater focus... is both desirable and inevitable".

According to the government paper, one implication of a strategy of concentration could be "a higher threshold for research funding". Last summer, officials in the department used similar arguments to back suggestions for the creation of a 'superleague', to which a limited number of universities - some suggest a dozen - would be admitted (see Nature 382, 381; 1996).

The idea has considerable (though not unanimous) support from institutions that are confident they would be included in this league, and which feel that their research efforts are in danger of being undermined by government efforts to spread scarce research funds too broadly.

Last month, for example, the vice-chancellors of the Universities of Cambridge, Warwick and Edinburgh, as well as University College London, wrote an article in The Observer newspaper suggesting such a move. They say this is necessary to counteract a general decline in standards in some academic subjects, in particular mathematics.

An earlier government position paper appears to endorse this view, saying that "neither teaching nor research is best served by allowing all universities and colleges to pursue necessarily limited research funds".

But the official submission to the Dearing inquiry highlights some of the drawbacks of such a scheme. It points out that excessive barriers between those designated as 'research universities' and other institutions "could stifle competition, prevent the development of emerging departments and discourage research projects which, though not necessarily of world class, are important to the regional or local economy".

Elsewhere, the paper says that, if not all higher education institutions were allowed to compete for research funds - as they do at present - "it would have to be decided how eligibility for research funds should be determined, without entrenching a new binary line and fossilizing research capability".

The government's support for greater collaboration between universities to create joint centres of excellence and share expensive equipment is likely to receive considerable backing from universities themselves, which are increasingly concerned with making cost-effective use of scarce resources. "This is very much what we have been suggesting," says Michael Powell, secretary of the research committee of the Committee of Vice-Chancellors and Principals.

The apparent decision not actively to endorse a 'superleague' is also likely to win widespread endorsement, particularly from institutions that fear such a move might exclude them from applying for research support from public funds.

\section{Congress turns the microscope on science spending}

[WASHINGTON] Increased monitoring of federal science agencies, aimed at ensuring that taxpayers get value for money, was revealed last week to be high on the agenda of the new chairman of the House of Representatives Science Committee for the committee's activities over the next two years.

James Sensenbrenner, the plain-speaking Wisconsin Republican who takes over from the retired Robert Walker of Pennsylvania, invited scientists to help decide how the value of research and development spending should be measured. He said he is "strongly opposed to Congress micromanaging federal agencies" but wants to achieve a consensus on broad programme goals for scientific spending. "If we're successful," he said, many

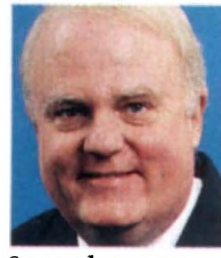

Sensenbrenner: seeking consensus. of the scientific controversies that plagued the last Congress "will die away".

Unlike his predecessor, Sensenbrenner does not foresee a single, cabinetlevel Department of Science. But he does think ence budget would be a "step in the right direction", as it would avoid pitting research spending against popular programmes such as housing and veterans' benefits, which are funded out of the same authorization bills.

The new chairman said he would like his committee to "look beyond the narrow issue of direct federal funding and management of science". He plans to hold committee hearings on corporate research and development to establish how government agencies can best use their investments to secure more private spending.

The new chairman, who formerly headed the committee's subcommittee on space, will start by focusing on subjects familiar to him. A priority is passing space legislation that went through the House last year but stalled in the Senate.

Sensenbrenner's first hearing, to be held this week, will be on Russian participation in the international space station project. $\mathrm{He}$ will travel to Russia and Europe next week with the new chair of the space subcommittee, Dana Rohrabacher (Republican, California), to assess the situation.

Other new Republican subcommittee chairs include Ken Calvert of California, who takes Rohrabacher's place as head of the subcommittee on energy and the environment; Constance Morella of Maryland, who will remain the chair of the technology subcommittee; and Steven Schiff of New Mexico, who stays as head of the committee's basic research subcommittee.
Tony Reichhardt 